\title{
Study of Acid Catalyzed Reactions of Proton Pump Inhibitors at D.M.E.
}

\author{
Hanuman P. Gupta, Kalawati Saini, Priyanka Dhingra and R. Pandey ${ }^{*}$ \\ Department of Chemistry University of Rajasthan Jaipur, India
}

Received 26 October 2007; accepted 1 April 2008

\begin{abstract}
Acid catalyzed reactions of three proton pump inhibitors (PPIs), namely omeprazole, lansoprazole and pantoprazole, have been investigated and monitored by direct current polarography at dropping mercury electrode (D.M.E) in phosphate buffer $(0.1 \mathrm{M}) \mathrm{of} \mathrm{pH}$ 3-7.5. This gives well defined current-time profiles of individual electroactive degradation products along with their starting materials. The investigation shows that the order of stability of three PPIs can be written as: pantoprazole $>$ omeprazole $>$ lansoprazole. The rate of degradation of PPIs decreases with decreasing the basicity of the corresponding benzimidazole nitrogen of PPIs, as predicted by the effect of individual substituents on each of the benzimidazole rings. At $\mathrm{pH} 7.5$ all three PPIs are almost stable and the observed half wave potentials $\left(\mathrm{E}_{1 / 2}\right)$ are $-1.07 \mathrm{~V}$ for omeprazole, $1.25 \mathrm{~V}$ for lansoprazole and $-1.32 \mathrm{~V}$ for pantoprazole. On decreasing the $\mathrm{pH}$ from 7.5 to 3.0 the anodic shift in $\mathrm{E}_{1 / 2}$ values were observed along with degradation of the PPIs and simultaneous appearance of degradation products. The present study may provide an insight for designing more potent new proton pump inhibitors.
\end{abstract}

Keywords: polarography, stability, proton pump inhibitors (PPIs), half wave potential.

\section{Introduction}

Inhibition of gastric acid secretion has been the major means of treatment of acid related diseases such as peptic ulcers and gastro-esophageal reflux disease. The first medicinal target to be identified was the histamine- 2 receptor, the major, but not the only-one, activating parietal cell receptor. The second medicinal target was the gastric acid pump, the gastric $(\mathrm{H}+, \mathrm{K}+)$-ATPase. Since proton transport by the gastric $(\mathrm{H}+, \mathrm{K}+)$-ATPase is the final step in acid secretion, it was

\footnotetext{
* Corresponding author. E-mail address: kalawati.saini@gmail.com.

* Corresponding author. E-mail address: kala.iitdchem@gmail.com
} 
anticipated that drugs of this type would be more effective inhibitor of acid secretion.

Omeprazole was the first clinically useful compound of this class and it was introduced in 1989 [1]. Its structure, 5-methoxy-2-[(4-methoxy-3,5-dimethyl-2ridinyl)methylsulfinyl]- $1 H$-benzimidazole, shown in scheme 1 , is similar to the structures of the other commonly used PPIs, lansoprazole and pantoprazole, which all have a benzimidazole.<smiles>COc1ccc2[nH]c(S(=O)Cc3ncc(C)c(OC)c3C)nc2c1</smiles>

Scheme 1<smiles>Cc1c(OCC(F)(F)F)ccnc1CSc1nc2ccccc2[nH]1</smiles>

Scheme 2<smiles>COc1ccc2c(c1)nc(SCc1nccc(OC)c1OC)n2N</smiles>

Pantoprazole

\section{Scheme 3}

PPIs consist of two heterocyclic moieties. One is a pyridine moiety, and the other is a benzimidazole or an imidazo-pyridine. The two heterocyclic moieties are linked through a methylenesulfinyl (- $\left.\mathrm{CH}_{2} \mathrm{SO}-\right)$ group. Clinically available proton pump inhibitors are omeprazole, $S$-omeprazole ( $S$-enantiomer of omeprazole), lansoprazole, pantoprazole, and rabeprazole. Lansoprazole is 2-[3-methyl-4(2,2,2-trifluoroethoxy)-

Pantoprazole is

pyridin-2-yl]methylsulfinyl]- $1 H$-benzimidazole. yl)methylsulfinyl]-1H-benzimidazole. Rabeprazole is 2-[4-(3-methoxypropoxy)3-methyl-pyridine-2-yl]methylsulfinyl- $1 H$-benzimidazole.

The chemistry of proton pump inhibitors (PPIs), including omeprazole, lansoprazole and pantoprazole, led to a new era in the effective therapy of acidpeptic diseases. Gastric PPIs are pro-drugs that require an acid induced activation. These are weak bases and are converted to the active form by gastric acid before acting on the proton pump. The proposed mode of action involves inhibition of gastric acid secretion into the lumen of the stomach by blockage of $(\mathrm{H}+/ \mathrm{K}+)$ ATPase (proton pump) of the parietal cell.[1-9]

PPIs break down rapidly in an acidic medium and thus must be administrated in the form of enteric-coated granules in capsules, to prevent gastric decomposition and improve their systematic bioavailability [10-11]. PPIs have different 
pyridinic and benzimidazole substituents which directly impact their mechanism of action and directly affect their rates of reactions. The pKa of these PPIs are 3.8 for pantoprazole, 3.9 for lansoprazole and 4.0 for omeprazole.

There have been several reports for the determination of omeprazole (I), lansoprazole (II), and pantoprazole (III) in formulations including colorimetric or spectrophotometric methods [12-17], TLC densitometry [18,19] and highperformance liquid chromatography [20].

Electroanalytical techniques have been used for the determination of a wide range of pharmaceuticals with the advantages that there is in most instances, no need for derivatization, and that these methods are less sensitive to matrix effects than other analytical techniques [21]. The reduction process and quantitative determination of lansoprazole and omeprazole have been studied by means of several polarographic techniques [22-26].

It is known that in acidic conditions, PPI transforms to a spiro intermediate of dihydrobenzimidazole as a result of acid catalysis which then undergoes aromatization to a sulfenic acid followed by dehydration to a tetracyclic sulphenamide. Smyth et al. (1994) used differential pulse polarography (DPP), UV spectrophotometry, spectrofluorimetry and liquid chromatography to monitor the degradation of benzimidazole sulphoxide antiulcer drug SK\&F 95601 and omeprazole in $\mathrm{HCl}$ at $\mathrm{pH} 2.0$ followed by reaction of 2-mercaptethanol with the respective products of degradation, as simulations of their believed reactions in vivo [27]. The work of Shin et al. (2004) [28 ] describes the stability of PPIs at various $\mathrm{pH}$ values by measuring the amounts of PPI that remained at different times. Shine et al investigated only the rate of degradation of PPIs using UV spectroscopy; no attempt was made to quantitatively evaluate or monitor the formation of degradation products.

Qaisi et al., 2006, worked on the acid degradation of omeprazole and investigated the mechanism for the inhibition of gastric $(\mathrm{H}+, \mathrm{K}+)$-adenosine triphosphate by omeprazole [29] . Tutunji et al., 2006, investigated acid degradation of omeprazole, lansoprazole and pantoprazole under the same experimental conditions using differential pulse polarography (DPP) at the static mercury drop electrode (SMDE) in phosphate buffer of $\mathrm{pH}$ 2.0-8.0 [30], and results were compared with previous techniques, which employed HPLC and UV spectroscopy, alone or in combination.

The present work is the investigation of acid catalyzed reactions of the same three PPIs, namely omeprazole, lansoprazole and pantoprazole, in solutions buffered to $\mathrm{pH}$ values 3.0-7.5 using direct current polarography at dropping mercury electrode.

Scheme 4, of acid catalyzed degradation of omeprazole, was proposed by previous workers: 


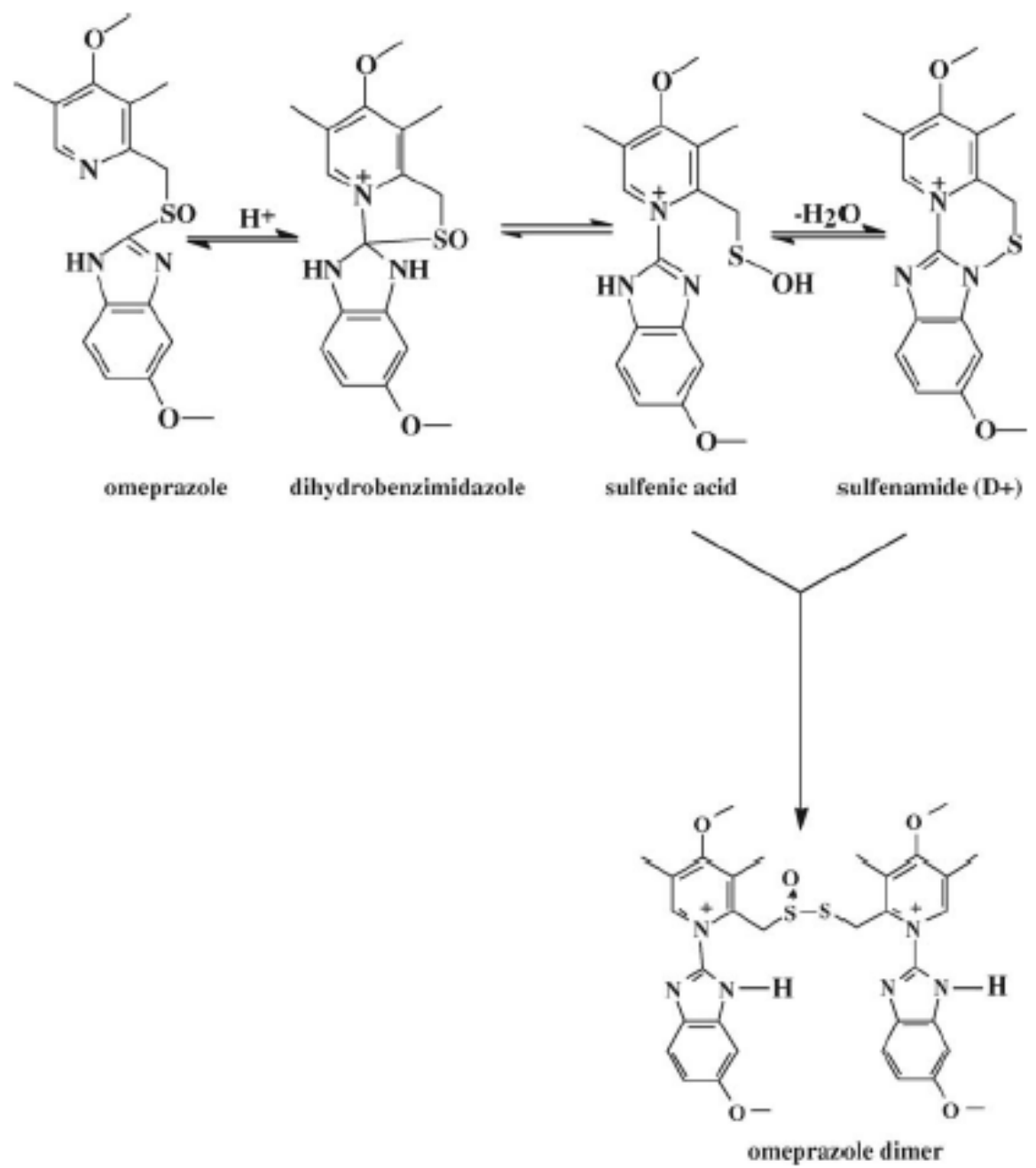

Scheme 4

\section{Experimental}

\section{Chemicals and reagents}

Omeprazole, pantoprazole and lansoprazole working standards were purchased from Metrochem API Private Limited, Hyderabad, India. Methanol was HPLC grade from Merck (Darmstadt, Germany). Phosphoric acid, potassium dihydrogen phosphate, dipotassium hydrogen phosphate, and trisodium phosphate were of AR grade from Merck (Darmstadt, Germany). All other reagents were used without further purification.

Ultrapure water was obtained by initially passing through two reversed osmosis cycles before initiating a distillation followed by a deionization step. Oxygen free nitrogen was used for deaeration, of each test solution, prior to initiating successive polarographic measurements.

\section{Instruments and apparatus}

An Elico (CL 357 ) digital DC polarographic analyzer was used to record current voltage plots. The current response and the applied potential were recorded at 
scan rate $150 \mathrm{mV} / \mathrm{min}$. The current voltage measurement were performed with three electrode assembly, a dropping mercury electrode (DME) as a working electrode, saturated calomel electrode (SCE) as reference electrode, and platinum electrode as counter electrode. A digital pH meter Elico (111E) (glass electrode C2K108030) was used for preparation of different buffer solutions.

\section{Sample solution}

PPIs are unstable under acidic conditions while these can be stored at $\mathrm{pH} 7.5$-9.0 for 4 days at room temperature without any degradation. Thus standard solutions of three PPIs were prepared by dissolving the accurate quantity of drug in a 5.0 $\mathrm{mL}$ sample tube, sealed with septum, stored at $4{ }^{\circ} \mathrm{C}$ in dark, and the required amount of sample was withdrawn with the help of a $500 \mu \mathrm{L}$ micro syringe at the time need.

Weighed accurately $69.1 \mathrm{mg}$ of omeprazole in a $5.0 \mathrm{~mL}$ sample tube, closed with septum followed by the addition of $200 \mu \mathrm{L}$ of $0.10 \mathrm{M} \mathrm{NaOH}$ solution and of $1800 \mu \mathrm{L}$ of distilled water, with the help of a micro syringe, and shake well to get a clear $2.0 \mathrm{~mL}(0.10 \mathrm{M})$ omeprazole solution of $\mathrm{pH} 9$.

Weighed accurately $76.7 \mathrm{mg}$ of pantoprazole in a $5.0 \mathrm{~mL}$ sample tube, closed with septum followed by the addition of $200 \mu \mathrm{L}$ of $0.10 \mathrm{M} \mathrm{NaOH}$ solution and of $1800 \mu \mathrm{L}$ of distilled water with the help of a micro syringe, and shake well to get a clear $2.0 \mathrm{~mL}(0.10 \mathrm{M})$ omeprazole solution of $\mathrm{pH} 9$. Weighed accurately $73.9 \mathrm{mg}$ of lansoprazole in a $5.0 \mathrm{~mL}$ sample tube, closed with septum followed by the addition of $200 \mu \mathrm{L}$ of $0.10 \mathrm{M} \mathrm{NaOH}$ solution and of $1800 \mu \mathrm{L}$ of distilled water with the help of micro syringe, and shake well to get a clear $2.0 \mathrm{~mL}(0.10$ M) omeprazole solution of $\mathrm{pH} 9$.

\section{Procedures}

After adjusting the $\mathrm{pH}$ of individual phosphate buffer solutions $(0.1 \mathrm{M})$ to the experimental value, a $10.0 \mathrm{~mL}$ aliquot was pipetted into the polarographic vessel. Deaeration was started by passing nitrogen gas for 15 minutes, a background signal was measured prior to introducing PPI $(100 \mu \mathrm{L} 0.10 \mathrm{M})$. This was immediately followed by initiating successive recordings of individual polarograms. Recordings were repeated until the PPI degraded completely and no analytical signal (current, $\mu \mathrm{A}$ ) was detected. DC polarograms were scanned between -0.30 and $-1.70 \mathrm{~V}$ at DME versus $\mathrm{SCE}$ at scan rate $150 \mathrm{mV} / \mathrm{min}$. Half wave potential( $\mathrm{E}_{1 / 2}$ (Volts versus $\left.\mathrm{SCE}\right)$ and peak current $(\mathrm{s})(\mu \mathrm{A})$ were recorded. The same procedures were followed using constant concentrations of individual PPI's $\left(1.0 \times 10^{-3} \mathrm{M}\right)$. Each solution was buffered to a different $\mathrm{pH}$ value including: 3.0, 4.0, 5.0, 6.0 and 7.5. Peak currents $(\mu \mathrm{A})$, half wave potential( $\left.\mathrm{E}_{1 / 2}\right)$ (Volts versus SCE) and time (minutes) were tabulated for all measurements.

\section{Results and discussion}

\section{Acid decomposition of PPIs}

The three PPIs $\left(10^{-3} \mathrm{M}\right)$ show similar well defined reduction peaks in $0.1 \mathrm{M}$ phosphate buffer of $\mathrm{pH} 7.5$ at d.m.e., due to reduction of sulphoxide group. The reduction potentials of the three PPIs at $\mathrm{pH} 7.5$ are shown in table 1 , and they are 
comparable with previous works [29-30]. Similarly to omeprazole (Qaisi et al., 2006, Tutunji et al., 2006), it was observed that the reduction potential(s) of lansoprazole and pantoprazole shift cathodically, as the solution $\mathrm{pH}$ increases from 3 to 7.5. This indicates that the protonation of the electroactive site of the molecule affects the overall electrode reaction mechanism.

Table 1. Half wave potentials (Volts) of three PPIs in $0.1 \mathrm{M}$ phosphate buffer of different $\mathrm{pH}$ at D.M.E.

\begin{tabular}{|c|c|c|c|c|}
\hline S.No. & $\mathrm{pH}$ & omeprazole & lansoprazole & pantoprazole \\
\hline 1 & 3 & -0.65 & -0.69 & -0.67 \\
\hline $\mathrm{s} 2$ & 4 & -0.67 & -0.71 & -0.75 \\
\hline 3 & 5 & -0.74 & -0.89 & -0.98 \\
\hline 4 & 6 & -0.85 & -1.04 & -1.15 \\
\hline 5 & 7.5 & -1.07 & -1.25 & -1.32 \\
\hline
\end{tabular}

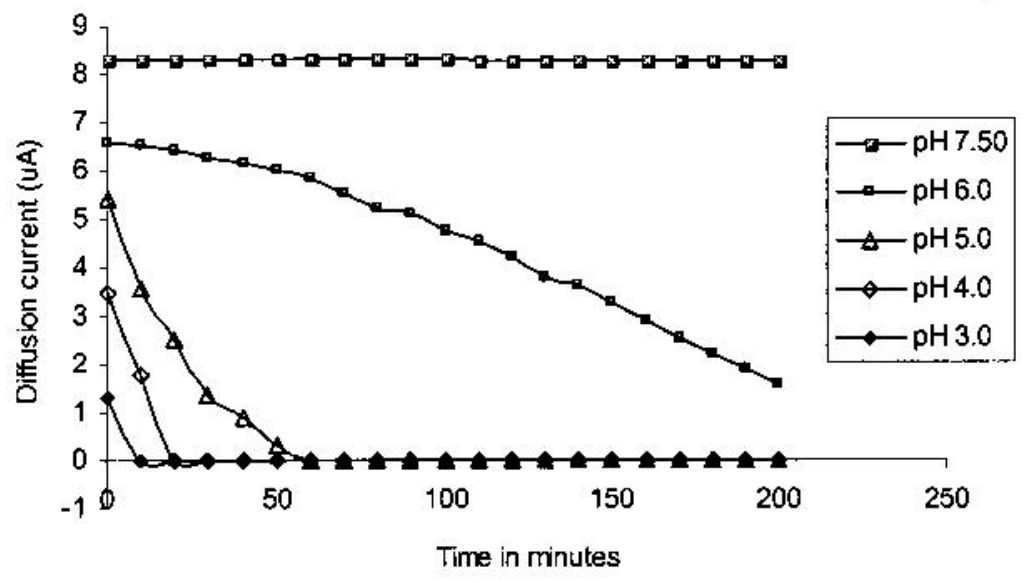

Figure 1. Current-time curve showing degradation of omeprazole at different $\mathrm{pH}$.

Fig. 1-3 and tables 2-4 show the degradation of PPIs in the $\mathrm{pH}$ rang 3-7.5. The order of time for degradation of PPIs at different $\mathrm{pH}$ is: lansoprazole > omeprazole $>$ pantoprazole. A similar order was observed by previous workers (Shin et al., 2004).

At pH 7.5 all three PPIs show apparent stability up to 200 minutes. At pH 6.0 the degradation of pantoprazole is slower than that of omeprazole and lansoprazole. As the $\mathrm{pH}$ decreases, the degradation of PPIs becomes more and more faster. Below $\mathrm{pH} 3.0$ the degradation is so fast that it is very difficult to observe the single measurement using DC polarography. 


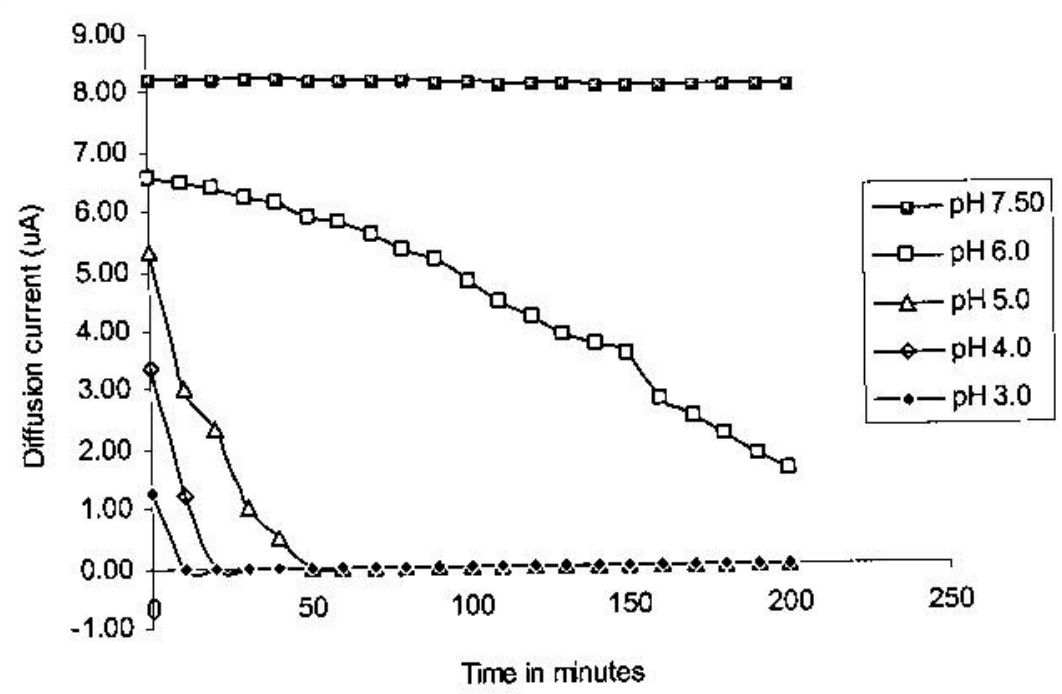

Figure 2. Current-time curve for degradation of lansoprazole at different $\mathrm{pH}$.

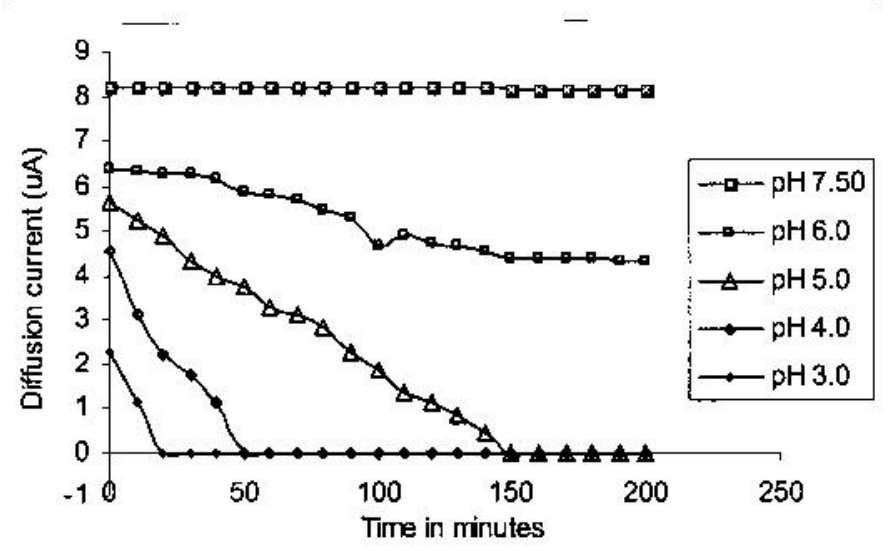

Figure 3. Current-time curve for degradation of pantoprazole at different $\mathrm{pH}$.

Acid-catalyzed degradation of PPIs depends mainly on protonation of the imidazole nitrogen. The basicity of the benzimidazole nitrogen seems to be the factor which plays a major role in determining the rate of degradation of each PPI. The methoxy group of omeprazole is not in direct resonance with the nitrogens of benzimidazole. Consequently, due to inductive effect (electron withdrawing effect), it is expected to decrease the basicity of the benzimidazole nitrogen compared with lansoprazole, which has no substituent on the benzimidazole ring. The benzimidazole ring of pantoprazole is expected to have the least basic nitrogen because of its more electron withdrawing substituents on the benzimidazole ring $\left(\mathrm{OCF}_{2} \mathrm{H}\right)$ compared with omeprazole. One may, therefore, arrange the theoretical basicity of benzimidazole nitrogen, with respect to the inductive effect of substituents, in the following order: lansoprazole > omeprazole $>$ pantoprazole. This consists with the observed rates of degradation of the investigated PPIs. 
Table 2. Degradation of omeprazole at different $\mathrm{pH}$.

\begin{tabular}{|c|c|c|c|c|c|c|c|c|c|c|c|}
\hline Time in & $\mathrm{pH}$ & $\mathrm{pH}$ & $\mathrm{pH}$ & $\mathrm{pH}$ & $\mathrm{pH}$ & Time in & $\mathrm{pH}$ & $\mathrm{pH}$ & $\mathrm{pH}$ & $\mathrm{pH}$ & $\mathrm{pH}$ \\
minutes & 7.50 & 6.0 & 5.0 & 4.0 & 3.0 & minutes & 7.50 & 6.0 & 5.0 & 4.0 & 3.0 \\
\hline 0 & 8.32 & 6.60 & 5.41 & 3.45 & 1.32 & 110 & 8.28 & 4.55 & 0.00 & 0.00 & 0.00 \\
\hline 10 & 8.32 & 6.51 & 3.56 & 1.8 & 0.00 & 120 & 8.28 & 4.22 & 0.00 & 0.00 & 0.00 \\
\hline 20 & 8.31 & 6.40 & 2.51 & 0.00 & 0.00 & 130 & 8.28 & 3.81 & 0.00 & 0.00 & 0.00 \\
\hline 30 & 8.32 & 6.25 & 1.35 & 0.00 & 0.00 & 140 & 8.28 & 3.61 & 0.00 & 0.00 & 0.00 \\
\hline 40 & 8.31 & 6.15 & 0.87 & 0.00 & 0.00 & 150 & 8.28 & 3.25 & 0.00 & 0.00 & 0.00 \\
\hline 50 & 8.29 & 5.98 & 0.32 & 0.00 & 0.00 & 160 & 8.27 & 2.88 & 0.00 & 0.00 & 0.00 \\
\hline 60 & 8.30 & 5.85 & 0.00 & 0.00 & 0.00 & 170 & 8.27 & 2.55 & 0.00 & 0.00 & 0.00 \\
\hline 70 & 8.29 & 5.55 & 0.00 & 0.00 & 0.00 & 180 & 8.27 & 2.22 & 0.00 & 0.00 & 0.00 \\
\hline 80 & 8.29 & 5.23 & 0.00 & 0.00 & 0.00 & 190 & 8.27 & 1.88 & 0.00 & 0.00 & 0.00 \\
\hline 90 & 8.29 & 5.11 & 0.00 & 0.00 & 0.00 & 200 & 8.27 & 1.60 & 0.00 & 0.00 & 0.00 \\
\hline 100 & 8.29 & 4.76 & 0.00 & 0.00 & 0.00 & \multicolumn{10}{|c|}{} & & & & \\
\hline
\end{tabular}

Table 3. Degradation of lansoprazole at different $\mathrm{pH}$.

\begin{tabular}{|c|c|c|c|c|c|c|c|c|c|c|c|}
\hline $\begin{array}{l}\text { Time in } \\
\text { minutes }\end{array}$ & $\begin{array}{c}\mathrm{pH} \\
7.50\end{array}$ & $\begin{array}{l}\mathrm{pH} \\
6.0\end{array}$ & $\begin{array}{l}\mathrm{pH} \\
5.0\end{array}$ & $\begin{array}{l}\mathrm{pH} \\
4.0\end{array}$ & $\begin{array}{l}\mathrm{pH} \\
3.0\end{array}$ & $\begin{array}{l}\text { Time in } \\
\text { minutes }\end{array}$ & $\begin{array}{c}\mathrm{pH} \\
7.50\end{array}$ & $\begin{array}{l}\mathrm{pH} \\
6.0\end{array}$ & $\begin{array}{l}\mathrm{pH} \\
5.0\end{array}$ & $\begin{array}{l}\mathrm{pH} \\
4.0\end{array}$ & $\begin{array}{l}\mathrm{pH} \\
3.0\end{array}$ \\
\hline 0 & 8.22 & 6.56 & 5.32 & 3.36 & 1.25 & 110 & 8.11 & 4.43 & 0.00 & 0.00 & 0.00 \\
\hline 10 & 8.23 & 6.49 & 3.02 & 1.24 & 0.00 & 120 & 8.11 & 4.18 & 0.00 & 0.00 & 0.00 \\
\hline 20 & 8.22 & 6.38 & 2.35 & 0.00 & 0.00 & 130 & 8.11 & 3.87 & 0.00 & 0.00 & 0.00 \\
\hline 30 & 8.21 & 6.23 & 1.01 & 0.00 & 0.00 & 140 & 8.08 & 3.71 & 0.00 & 0.00 & 0.00 \\
\hline 40 & 8.21 & 6.14 & 0.51 & 0.00 & 0.00 & 150 & 8.08 & 3.55 & 0.00 & 0.00 & 0.00 \\
\hline 50 & 8.18 & 5.88 & 0.00 & 0.00 & 0.00 & 160 & 8.08 & 2.75 & 0.00 & 0.00 & 0.00 \\
\hline 60 & 8.17 & 5.79 & 0.00 & 0.00 & 0.00 & 170 & 8.07 & 2.45 & 0.00 & 0.00 & 0.00 \\
\hline 70 & 8.17 & 5.56 & 0.00 & 0.00 & 0.00 & 180 & 8.07 & 2.15 & 0.00 & 0.00 & 0.00 \\
\hline 80 & 8.17 & 5.31 & 0.00 & 0.00 & 0.00 & 190 & 8.07 & 1.83 & 0.00 & 0.00 & 0.00 \\
\hline 90 & 8.15 & 5.16 & 0.00 & 0.00 & 0.00 & 200 & 8.07 & 1.55 & 0.00 & 0.00 & 0.00 \\
\hline 100 & 8.14 & 4.79 & 0.00 & 0.00 & 0.00 & & & & & & \\
\hline
\end{tabular}

\section{The cyclic sulfenamides of PPIs}

The cyclic sulfenamides of three PPIs show well defined polarographic reduction peaks in 0.1 M phosphate buffer if $\mathrm{pH}$ is less than 6.0, as shown in Fig. 4-6 and tables 5-8. The order of rate of appearance of cyclic sulfenamide is: lansoprazole $>$ omeprazole $>$ pantoprazole. The rate of appearance of cyclic sulfenamide of pantoprazole at $\mathrm{pH} 6.0$ is very slow (Fig. 6), indicating the highest stability of pantoprazole at $\mathrm{pH} 6.0$ than that of omeprazole and lansoprazole. The stability order of three PPIs at $\mathrm{pH}$ 6-3 can be written as pantoprazole $>$ omeprazole $>$ lansoprazole. In the structure of cyclic sulfenamide there is positive charge on the nitrogen of sulfonam ring and any electron-donating group will be able to stabilize the positive charge on the sulfonam ring of the cyclic sulfonamide. The cyclic sulfonamide of omeprazole get stabilized with electron donating methoxy group hence it should be more stable than cyclic sulfonamide of lansoprazole. Hence the stability order of three cyclic sulfenamides results in the following order in acidic medium: pantoprazole $>$ omeprazole $>$ lansoprazole. 
Table 4. Degradation of pantoprazole at different $\mathrm{pH}$.

\begin{tabular}{|c|c|c|c|c|c|c|c|c|c|c|c|}
\hline $\begin{array}{l}\text { Time in } \\
\text { minutes }\end{array}$ & $\begin{array}{c}\mathrm{pH} \\
7.50\end{array}$ & $\begin{array}{l}\mathrm{pH} \\
6.0\end{array}$ & $\begin{array}{l}\mathrm{pH} \\
5.0\end{array}$ & $\begin{array}{l}\mathrm{pH} \\
4.0\end{array}$ & $\begin{array}{l}\mathrm{pH} \\
3.0\end{array}$ & $\begin{array}{l}\text { Time in } \\
\text { minutes }\end{array}$ & $\begin{array}{c}\mathrm{pH} \\
7.50\end{array}$ & $\begin{array}{l}\mathrm{pH} \\
6.0\end{array}$ & $\begin{array}{l}\mathrm{pH} \\
5.0\end{array}$ & $\begin{array}{l}\mathrm{pH} \\
4.0\end{array}$ & $\begin{array}{l}\mathrm{pH} \\
3.0\end{array}$ \\
\hline 0 & 8.21 & 6.35 & 5.65 & 4.55 & 2.25 & 110 & 8.19 & 4.88 & 1.32 & 0.00 & 0.00 \\
\hline 10 & 8.21 & 6.31 & 5.23 & 3.12 & 1.11 & 120 & 8.19 & 4.71 & 1.11 & 0.00 & 0.00 \\
\hline 20 & 8.19 & 6.27 & 4.89 & 2.21 & 0.00 & 130 & 8.18 & 4.65 & 0.85 & 0.00 & 0.00 \\
\hline 30 & 8.19 & 6.23 & 4.31 & 1.75 & 0.00 & 140 & 8.18 & 4.55 & 0.45 & 0.00 & 0.00 \\
\hline 40 & 8.20 & 6.17 & 4.00 & 1.11 & 0.00 & 150 & 8.17 & 4.36 & 0.00 & 0.00 & 0.00 \\
\hline 50 & 8.21 & 5.83 & 3.73 & 0.00 & 0.00 & 160 & 8.17 & 4.36 & 0.00 & 0.00 & 0.00 \\
\hline 60 & 8.21 & 5.79 & 3.26 & 0.00 & 0.00 & 170 & 8.17 & 4.35 & 0.00 & 0.00 & 0.00 \\
\hline 70 & 8.21 & 5.66 & 3.11 & 0.00 & 0.00 & 180 & 8.17 & 4.35 & 0.00 & 0.00 & 0.00 \\
\hline 80 & 8.22 & 5.46 & 2.85 & 0.00 & 0.00 & 190 & 8.17 & 4.34 & 0.00 & 0.00 & 0.00 \\
\hline 90 & 8.21 & 5.26 & 2.25 & 0.00 & 0.00 & 200 & 8.17 & 4.34 & 0.00 & 0.00 & 0.00 \\
\hline 100 & 8.19 & 4.65 & 1.88 & 0.00 & 0.00 & & & & & & \\
\hline
\end{tabular}

Table 5. Half wave potentials (Volt) of cyclic sulfenamides of three PPIs at different $\mathrm{pH}$ in phosphate buffer $(0.1 \mathrm{M})$

\begin{tabular}{|c|c|c|c|c|}
\hline S.No. & $\mathrm{pH}$ & omeprazole & lansoprazole & pantoprazole \\
\hline 1 & 6 & -1.14 & -1.41 & -1.48 \\
\hline 2 & 5 & -0.98 & -1.23 & -1.33 \\
\hline 3 & 4 & -0.94 & -0.98 & -0.98 \\
\hline 4 & 3 & -0.91 & -0.96 & -0.96 \\
\hline
\end{tabular}

The behavior of appearance of sulfenamide in all these three cases of PPIs is similar, diffusion current increases initially with increase the concentration of cyclic sulfenamide (due to high concentration of PPI) and reaches the maximum value, but soon with time cyclic sulfenamide starts converting to its dimer simultaneously and hence diffusion current decreases. The value of diffusion current becomes almost constant at $\mathrm{pH} 5-6$, indicating that the rate of appearance of cyclic sulfenamide becomes almost equal to its rate of conversion into its dimer. At $\mathrm{pH}$ below 5.0 the diffusion current becomes almost zero because of fast conversion of cyclic sulfenamide into its dimer. The values of half wave potential of cyclic sulfenamides at different $\mathrm{pH}$ are shown in table 5. The half wave potential $\left(\mathrm{E}_{1 / 2}\right)$ shows more negative shift (cathodic shift) with increase in $\mathrm{pH}$ of solution. 


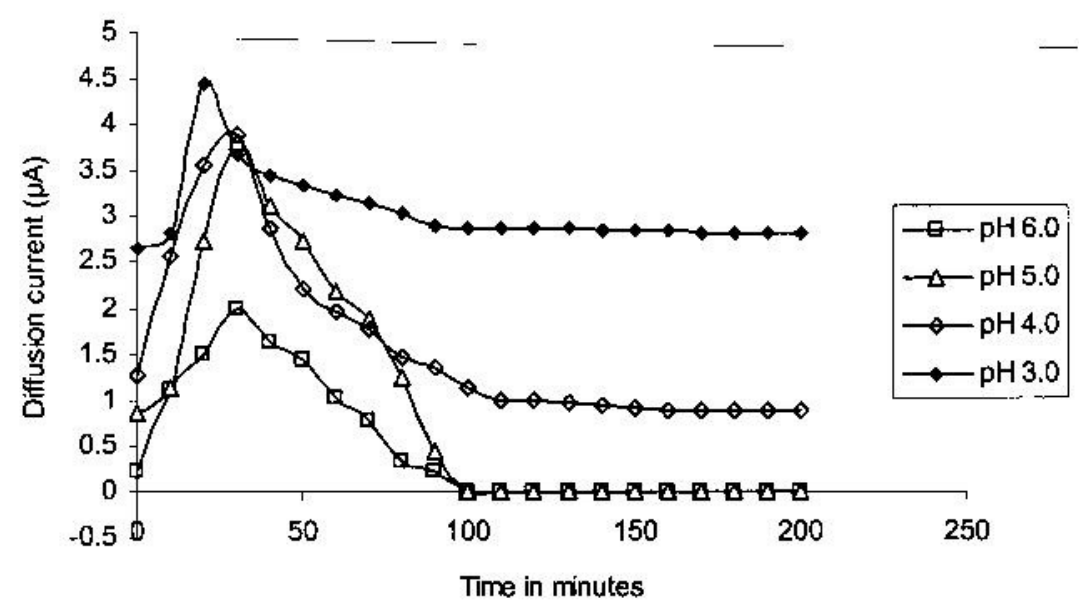

Figure 4. Current-time curve for appearance of cyclic sulfenamide of omeprazole at different $\mathrm{pH}$.

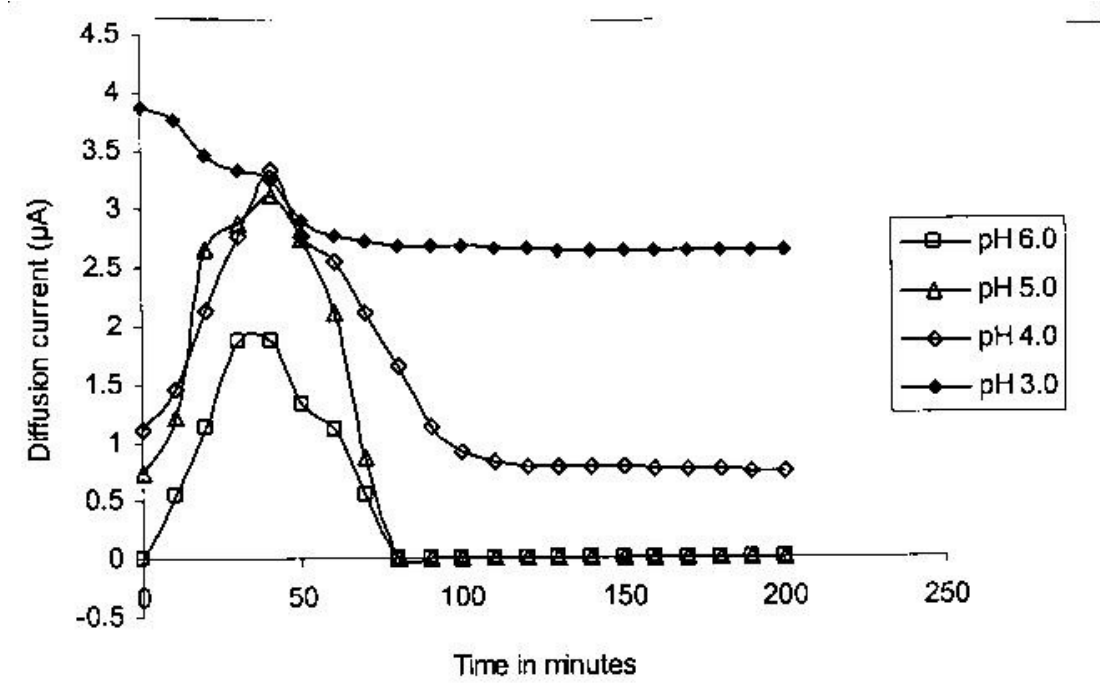

Figure 5. Current-time curve for appearance of cyclic sulfenamide of lansoprazole at different $\mathrm{pH}$. 


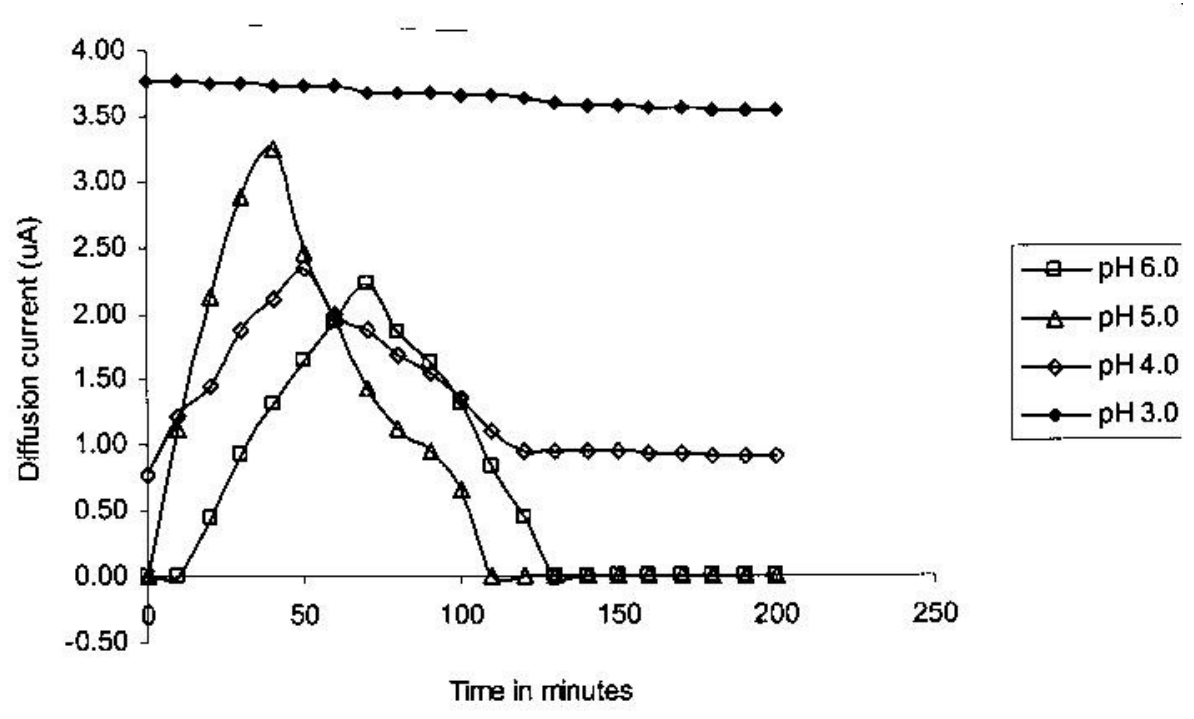

Figure 6. Current-time curve for appearance of cyclic sulfenamides of pantoprazole at different $\mathrm{pH}$.

\section{Appearance of dimers of PPIs}

The half wave potential of dimers of three PPIs are shown in table 9. The anodic shift has been reported on decreasing the $\mathrm{pH}$ of solution but shift is not as much as observed for individual PPIs and related cyclic sulfenamide. The order of rate of appearance of dimer can be written as: lansoprazole > omeprazole > pantoprazole. As shown in Fig. 7-8 and tables 10-12, the appearance of dimers of all PPIs follows the same trend. At a particular $\mathrm{pH}$ the dimer appears linearly with time and reaches to maximum concentration and than becomes constant. The slope of linear part of the curve increases with decrease in $\mathrm{pH}$ of the solution, in other words, we can conclude that the rate of appearance of dimer at particular concentration of PPI increases with $\mathrm{pH}$ of the solution.

Table 6. Appearance of cyclic sulfenamide of omeprazole at different $\mathrm{pH}$.

\begin{tabular}{|c|c|c|c|c|c|c|c|c|c|}
\hline $\begin{array}{c}\text { Time in } \\
\text { minutes }\end{array}$ & $\mathrm{pH}$ & $\mathrm{pH}$ & $\mathrm{pH}$ & $\mathrm{pH}$ & Time in & $\mathrm{pH}$ & $\mathrm{pH}$ & $\mathrm{pH}$ & $\mathrm{pH}$ \\
\hline 0 & 0.22 & 5.0 & 4.0 & 3.0 & minutes & 6.0 & 5.0 & 4.0 & 3.0 \\
\hline 10 & 1.11 & 1.12 & 2.56 & 2.66 & 110 & 0.00 & 0.00 & 1.00 & 2.87 \\
\hline 20 & 1.48 & 2.72 & 3.56 & 4.45 & 120 & 0.00 & 0.00 & 0.98 & 2.86 \\
\hline 30 & 1.98 & 3.81 & 3.89 & 3.66 & 140 & 0.00 & 0.00 & 0.96 & 2.86 \\
\hline 40 & 1.62 & 3.11 & 2.88 & 3.45 & 150 & 0.00 & 0.00 & 0.94 & 2.85 \\
\hline 50 & 1.43 & 2.74 & 2.22 & 3.34 & 160 & 0.00 & 0.00 & 0.91 & 2.85 \\
\hline 60 & 1.02 & 2.17 & 1.97 & 3.24 & 170 & 0.00 & 0.00 & 0.89 & 2.85 \\
\hline 70 & 0.76 & 1.88 & 1.76 & 3.15 & 180 & 0.00 & 0.00 & 0.89 & 2.83 \\
\hline 80 & 0.32 & 1.24 & 1.45 & 3.03 & 190 & 0.00 & 0.00 & 0.89 & 2.83 \\
\hline 90 & 0.21 & 0.45 & 1.36 & 2.89 & 200 & 0.00 & 0.00 & 0.89 & 2.83 \\
\hline 100 & 0.00 & 0.00 & 1.12 & 2.87 & & & & & \\
\hline
\end{tabular}


Table 7. Appearance of cyclic sulfenamide of lansoprazole at different $\mathrm{pH}$.

\begin{tabular}{|c|c|c|c|c|c|c|c|c|c|}
\hline $\begin{array}{c}\text { Time in } \\
\text { minutes }\end{array}$ & $\begin{array}{c}\mathrm{pH} \\
6.0\end{array}$ & $\begin{array}{c}\mathrm{pH} \\
5.0\end{array}$ & $\begin{array}{c}\mathrm{pH} \\
4.0\end{array}$ & $\begin{array}{c}\mathrm{pH} \\
3.0\end{array}$ & $\begin{array}{c}\text { Time in } \\
\text { minutes }\end{array}$ & $\begin{array}{c}\mathrm{pH} \\
6.0\end{array}$ & $\mathrm{pH}$ & $\mathrm{pH}$ & $\mathrm{pH}$ \\
\hline 0 & 0 & 0.75 & 1.11 & 3.88 & 110 & 0.00 & 0.00 & 0.0 & 3.0 \\
\hline 10 & 0.55 & 1.22 & 1.45 & 3.76 & 120 & 0.00 & 0.00 & 0.79 & 2.66 \\
\hline 20 & 1.12 & 2.65 & 2.12 & 3.45 & 130 & 0.00 & 0.00 & 0.79 & 2.64 \\
\hline 30 & 1.86 & 2.88 & 2.76 & 3.33 & 140 & 0.00 & 0.00 & 0.78 & 2.64 \\
\hline 40 & 1.87 & 3.11 & 3.33 & 3.24 & 150 & 0.00 & 0.00 & 0.78 & 2.64 \\
\hline 50 & 1.32 & 2.75 & 2.76 & 2.89 & 160 & 0.00 & 0.00 & 0.76 & 2.64 \\
\hline 60 & 1.11 & 2.11 & 2.54 & 2.76 & 170 & 0.00 & 0.00 & 0.76 & 2.64 \\
\hline 70 & 0.55 & 0.87 & 2.11 & 2.71 & 180 & 0.00 & 0.00 & 0.76 & 2.64 \\
\hline 80 & 0.00 & 0.00 & 1.66 & 2.68 & 190 & 0.00 & 0.00 & 0.75 & 2.64 \\
\hline 90 & 0.00 & 0.00 & 1.12 & 2.68 & 200 & 0.00 & 0.00 & 0.75 & 2.64 \\
\hline 100 & 0.00 & 0.00 & 0.92 & 2.68 & & & & &
\end{tabular}

Table 8. Appearance of cyclic sulfenamide of pantoprazole at different $\mathrm{pH}$.

\begin{tabular}{|c|c|c|c|c|c|c|c|c|c|}
\hline $\begin{array}{c}\text { Time in } \\
\text { minutes }\end{array}$ & $\mathrm{pH}$ & $\mathrm{pH}$ & $\mathrm{pH}$ & $\mathrm{pH}$ & Time in & $\mathrm{pH}$ & $\mathrm{pH}$ & $\mathrm{pH}$ & $\mathrm{pH}$ \\
\hline 0 & 0.00 & 0.00 & 0.78 & 3.76 & 110 & 0.83 & 0.00 & 1.11 & 3.65 \\
\hline 10 & 0.00 & 1.12 & 1.21 & 3.76 & 120 & 0.45 & 0.00 & 0.95 & 3.63 \\
\hline 20 & 0.45 & 2.13 & 1.45 & 3.74 & 130 & 0.00 & 0.00 & 0.95 & 3.59 \\
\hline 30 & 0.93 & 2.88 & 1.87 & 3.74 & 140 & 0.00 & 0.00 & 0.94 & 3.58 \\
\hline 40 & 1.32 & 3.25 & 2.11 & 3.72 & 150 & 0.00 & 0.00 & 0.94 & 3.58 \\
\hline 50 & 1.65 & 2.45 & 2.34 & 3.72 & 160 & 0.00 & 0.00 & 0.92 & 3.56 \\
\hline 60 & 1.93 & 1.97 & 2.00 & 3.72 & 170 & 0.00 & 0.00 & 0.92 & 3.56 \\
\hline 70 & 2.22 & 1.43 & 1.87 & 3.68 & 180 & 0.00 & 0.00 & 0.91 & 3.54 \\
\hline 80 & 1.85 & 1.12 & 1.68 & 3.68 & 190 & 0.00 & 0.00 & 0.91 & 3.54 \\
\hline 90 & 1.62 & 0.94 & 1.55 & 3.68 & 200 & 0.00 & 0.00 & 0.91 & 3.54 \\
\hline 100 & 1.32 & 0.65 & 1.35 & 3.66 & & & & & \\
\end{tabular}

Table 9. Half wave potentials of dimers of three PPIs at different $\mathrm{pH}$ in phosphate buffer $(0.1 \mathrm{M})$.

\begin{tabular}{|c|c|c|c|c|}
\hline S.No. & $\mathrm{pH}$ & omeprazole & lansoprazole & pantoprazole \\
\hline 1 & 6 & -0.63 & -0.71 & -0.78 \\
\hline 2 & 5 & -0.56 & -0.67 & -0.75 \\
\hline 3 & 4 & -0.51 & -0.55 & -0.58 \\
\hline 4 & 3 & -0.48 & -0.52 & -0.53 \\
\hline
\end{tabular}




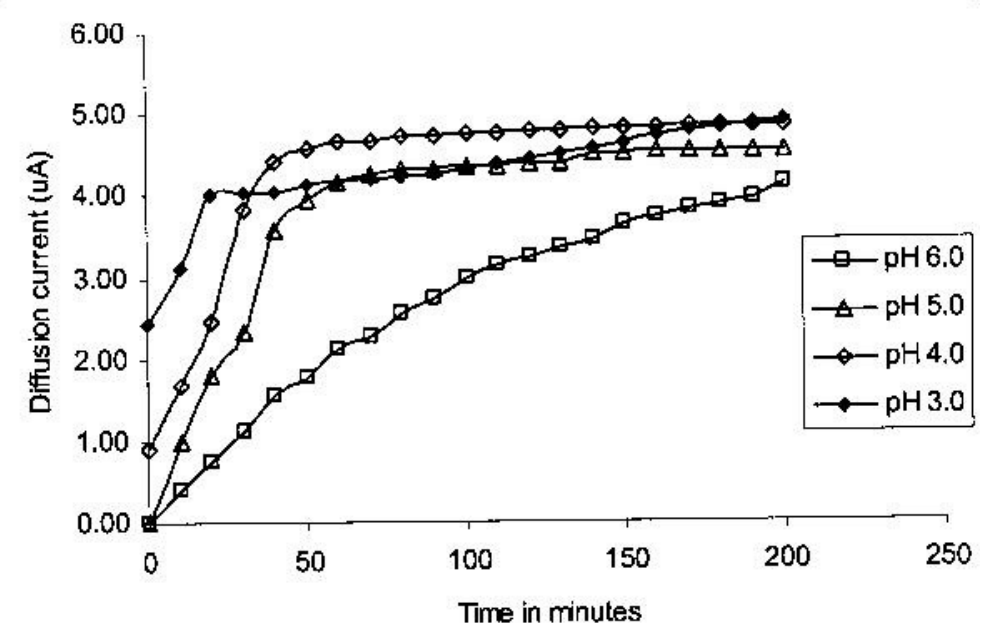

Figure 7. Current-time curve for appearance of dimmer of omeprazole at different $\mathrm{pH}$.

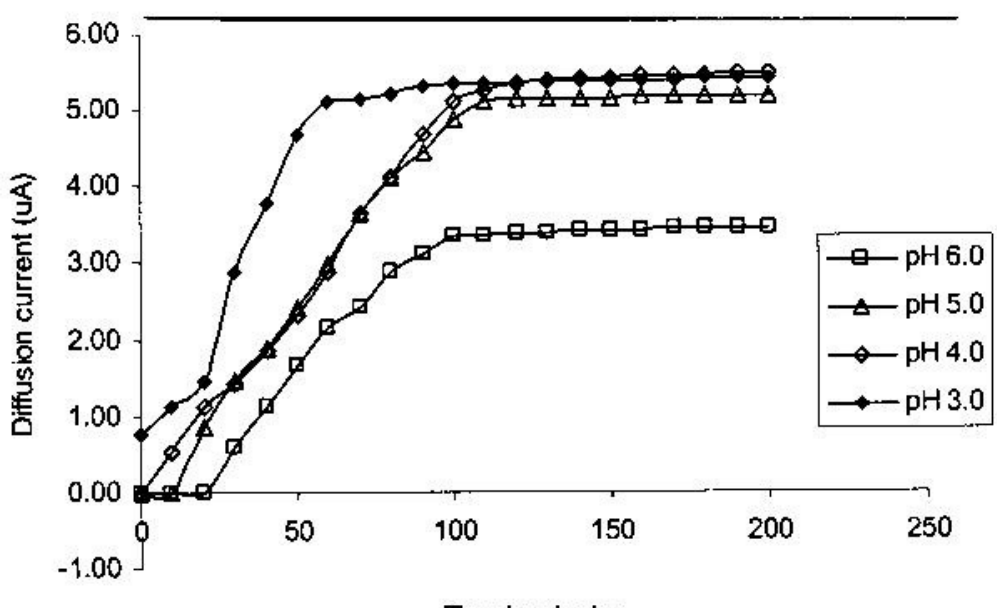

Time in minutes

Figure 8. Current-time curve for appearance of dimmers of pantoprazole at different $\mathrm{pH}$.

Table 10. Appearance of dimer of omeprazole at different $\mathrm{pH}$.

\begin{tabular}{|c|c|c|c|c|c|c|c|c|c|}
\hline $\begin{array}{c}\text { Time in } \\
\text { minutes }\end{array}$ & $\mathrm{pH} 6.0$ & $\mathrm{pH} 5.0$ & $\mathrm{pH} 4.0$ & $\mathrm{pH} 3.0$ & $\begin{array}{c}\text { Time in } \\
\text { minutes }\end{array}$ & $\mathrm{pH} 6.0$ & $\mathrm{pH} 5.0$ & $\mathrm{pH} 4.0$ & $\mathrm{pH} 3.0$ \\
\hline 0 & 0.00 & 0.00 & 0.89 & 2.43 & 110 & 3.14 & 4.36 & 4.76 & 4.37 \\
\hline 10 & 0.41 & 1.01 & 1.67 & 3.11 & 120 & 3.23 & 4.39 & 4.78 & 4.45 \\
\hline 20 & 0.75 & 1.81 & 2.45 & 4.01 & 130 & 3.36 & 4.39 & 4.78 & 4.51 \\
\hline 30 & 1.12 & 2.34 & 3.81 & 4.05 & 140 & 3.45 & 4.50 & 4.81 & 4.57 \\
\hline 40 & 1.56 & 3.56 & 4.40 & 4.05 & 150 & 3.63 & 4.51 & 4.82 & 4.62 \\
\hline 50 & 1.76 & 3.96 & 4.58 & 4.12 & 160 & 3.72 & 4.54 & 4.82 & 4.71 \\
\hline 60 & 2.11 & 4.17 & 4.65 & 4.16 & 170 & 3.81 & 4.54 & 4.84 & 4.79 \\
\hline 70 & 2.26 & 4.27 & 4.67 & 4.19 & 180 & 3.90 & 4.55 & 4.84 & 4.82 \\
\hline 80 & 2.54 & 4.31 & 4.71 & 4.22 & 190 & 3.96 & 4.55 & 4.86 & 4.87 \\
\hline 90 & 2.75 & 4.31 & 4.71 & 4.25 & 200 & 4.12 & 4.55 & 4.86 & 4.92 \\
\hline 100 & 2.97 & 4.36 & 4.75 & 4.31 & & & & & \\
\hline
\end{tabular}


Table 11. Appearance of dimer of lansoprazole at different $\mathrm{pH}$.

\begin{tabular}{|c|c|c|c|c|c|c|c|c|c|}
\hline $\begin{array}{c}\text { Time in } \\
\text { Minutes }\end{array}$ & $\mathrm{pH} 6.0$ & $\mathrm{pH} 5.0$ & $\mathrm{pH} 4.0$ & $\mathrm{pH} 3.0$ & $\begin{array}{c}\text { Time in } \\
\text { Minutes }\end{array}$ & $\mathrm{pH} 6.0$ & $\mathrm{pH} 5.0$ & $\mathrm{pH} 4.0$ & $\mathrm{pH} 3.0$ \\
\hline 0 & 0.00 & 0.00 & 0.86 & 2.47 & 110 & 3.25 & 4.37 & 4.81 & 4.56 \\
\hline 10 & 0.45 & 0.89 & 1.65 & 3.13 & 120 & 3.37 & 4.39 & 4.82 & 4.58 \\
\hline 20 & 0.76 & 1.57 & 2.55 & 4.05 & 130 & 3.46 & 4.41 & 4.84 & 4.78 \\
\hline 30 & 1.15 & 2.14 & 3.79 & 4.08 & 140 & 3.49 & 4.41 & 4.84 & 4.78 \\
\hline 40 & 1.59 & 2.89 & 4.42 & 4.11 & 150 & 3.53 & 4.41 & 4.86 & 4.79 \\
\hline 50 & 1.72 & 3.67 & 4.61 & 4.13 & 160 & 3.64 & 4.43 & 4.88 & 4.78 \\
\hline 60 & 2.25 & 4.13 & 4.66 & 4.16 & 170 & 3.68 & 4.43 & 4.88 & 4.82 \\
\hline 70 & 2.32 & 4.24 & 4.69 & 4.21 & 180 & 3.71 & 4.43 & 4.88 & 4.82 \\
\hline 80 & 2.56 & 4.31 & 4.72 & 4.24 & 190 & 3.75 & 4.43 & 4.91 & 4.82 \\
\hline 90 & 2.78 & 4.33 & 4.72 & 4.26 & 200 & 4.76 & 4.43 & 4.91 & 4.82 \\
\hline 100 & 2.93 & 4.38 & 4.76 & 4.29 & & & & & \\
\hline
\end{tabular}

Table 12. Appearance of dimer of pantoprazole at different $\mathrm{pH}$.

\begin{tabular}{|c|c|c|c|c|c|c|c|c|c|}
\hline $\begin{array}{c}\text { Time in } \\
\text { Minutes }\end{array}$ & $\mathrm{pH} \mathrm{6.0}$ & $\mathrm{pH} 5.0$ & $\mathrm{pH} 4.0$ & $\mathrm{pH} 3.0$ & $\begin{array}{c}\text { Time in } \\
\text { Minutes }\end{array}$ & $\mathrm{pH} 6.0$ & $\mathrm{pH} 5.0$ & $\mathrm{pH} 4.0$ & $\mathrm{pH} 3.0$ \\
\hline 0 & 0.00 & 0.00 & 0.00 & 0.76 & 110 & 3.35 & 5.12 & 5.23 & 5.32 \\
\hline 10 & 0.00 & 0.00 & 0.54 & 1.12 & 120 & 3.38 & 5.13 & 5.32 & 5.34 \\
\hline 20 & 0.00 & 0.87 & 1.11 & 1.47 & 130 & 3.38 & 5.13 & 5.38 & 5.36 \\
\hline 30 & 0.59 & 1.45 & 1.41 & 2.89 & 140 & 3.41 & 5.15 & 5.41 & 5.36 \\
\hline 40 & 1.11 & 1.87 & 1.85 & 3.78 & 150 & 3.41 & 5.15 & 5.41 & 5.36 \\
\hline 50 & 1.65 & 2.43 & 2.33 & 4.66 & 160 & 3.42 & 5.16 & 5.43 & 5.38 \\
\hline 60 & 2.15 & 2.97 & 2.88 & 5.11 & 170 & 3.46 & 5.16 & 5.43 & 5.38 \\
\hline 70 & 2.42 & 3.66 & 3.66 & 5.15 & 180 & 3.46 & 5.16 & 5.44 & 5.39 \\
\hline 80 & 2.88 & 4.11 & 4.12 & 5.21 & 190 & 3.46 & 5.16 & 5.46 & 5.39 \\
\hline 90 & 3.11 & 4.45 & 4.67 & 5.29 & 200 & 3.46 & 5.16 & 5.46 & 5.39 \\
\hline 100 & 3.34 & 4.88 & 5.11 & 5.32 & & & & & \\
\hline
\end{tabular}

\section{Conclusions}

The rate of degradation of the investigated PPIs depends on the basicity of benzimidazole nitrogen of individual PPIs. The investigation shows that the order of stability of three PPIs can be written as: pantoprazole $>$ omeprazole $>$ lansoprazole. The anodic shift in $\mathrm{E}_{1 / 2}$ of dimers has been reported on decreasing the $\mathrm{pH}$ of solution but shift is not as much as observed for individual PPIs and related cyclic sulfenamid. The order of rate of appearance of dimmers can be written as: lansoprazole $>$ omeprazole $>$ pantoprazole. Any electrone donating group on pyridinic moiety will be able to stabilize the positive charge on the sulfenam ring of the cyclic sulfenamide. Cyclic sulfonamide of omeprazole get stabilized with electron donating methoxy group hence it should be more stable cyclic sulfenamide of lansoprazole. The basicity of the benzimidazole nitrogen seems to be the factor which plays a major role in determining the rate of degradation of each PPI. The theoretical basicity of banzimidazole nitrogen with respect to the substituent is in the following order: lansoprazole $>$ omeprazole $>$ 
pantoprazole. The order of rate for degradation of PPIs at different $\mathrm{pH}$ is found to be lansoprazole $>$ omeprazole $>$ pantaprazole.

\section{References}

1. (a) V. Figala, K. Klemm, B. Kohl, U. Kruger, G. Rainer, H. Schaefer, J. Senn-Bilfinger and E. Sturm, Chem. Commun. (1986) 125; (b) P. Lindberg, A Brandstrom, B. Wallmark, H. Mattsson, L. Rikner, J. Med. Res. 10 (1990) 1-54.

2. W.A. Simon, D.J. Keeling, S.M. Laing, C. Fallowfield and A.G. Taylor, Biochem. Pharmacol. 39 (1990) 1799.

3. M. Morii, H. Takata, H. Fujisaki and N. Takeguchi, Biochem. Pharmacol. 39 (1990) 661.

4. J. Senn-Bilfinger, U. Kruger, E. Sturm, V. Figala, K. Klemm, B. Kohl, G. Rainer, H. Schaefer, T.J. Blake, D.W. Darkin, R.J. Ife, C.A. Leach, R.C. Mitchell, E.S. Pepper, C.J. Salter, N.J. Viney, G. Huttner and L. Zsolnai, J. Org. Chem. 52 (1987) 4582.

5. A. Brandstrom, P. Lindberg, N.A. Bergman, T. Alminger, K. Ankner, U. Junggren, B. Lamm, P. Nordberg, M. Erickson, I. Grundevik, I. Hagin, K.-J. Hoffmann, S. Johansson, S. Larsson, I. Liifberg, K. Ohlson, B. Persson, I. Skinberg and L. Tekenbergs-Hjelte, Acta Chem. Stand. 43 (1989) 536.

6. G. Rackur, M. Bickel, H.-W. Fehlhaber, A. Herling, V. Hitzel, H.-J. Lang, M. Riisner and R. Weyer, Biochem. Biophys. Res. Commun. 128 (1985) 477.

7. A.S. Mee, J.L. Rowley, Aliment. Pharmacol. Ther. 10 (1996) 757- 763.

8. D. Jaspersen, K.L. Diehl, H. Schoeppner, P. Geyer, E.A. Martens, Aliment. Pharmacol. Ther. 12 (1998) 49-52.

9. H. Nagaya, H. Satoh, Y. Maki, Eur. J. Clin. Pharmacol. 45 (1993) 367-371.

10. S.K. Garg, Y. Chugh, S.K. Tripathi, N. Kumar, P.L. Sharma, Int. J. Clin. Pharmacol. Ther. 31 (1993) 96-99.

11. C.M. Spencer, D. Faulds, Indian Drugs 48 (1994) 404-430.

12. C.S.P. Sastry, Y.P. Naidu, S.S.N. Murty, Indian Drugs 33 (1996) 607-610.

13. C.S.P. Sastry, P.Y. Naidu, S.S.N. Murty, Talanta 44 (1997) 1211-1217.

14. A.M. Wahbi, O. Abdel-Razak, A.A. Gazy, H. Mahgoub, M.S. Moneeb, J. Pharm. Biomed. Anal. 30 (2002) 1133-1142.

15. N. Ozaltin, J. Pharm. Biomed. Anal. 20 (1999) 599-606.

16. N. Ozaltin, A. Kocer, J. Pharm. Biomed. Anal. 16 (1997) 337-342.

17. D. Dogrukol, Z. Tumalier, M. Tuncel, Pharmazie 53 (1998) 272-273.

18. S.N. Meyyanathan, J.R.A. Raj, B. Suresh, Indian Drugs 34 (1997) 403-406.

19. S. Ray, P. Kumar-De, Indian Drugs 31 (1994) 543-547.

20. N. Badwe, G.C. Kandpal, S.T. Hathiari, East Pharm. 39 (1996) 127-128.

21. M.A. Brooks, in: P.T. Kissinger, W.R. Heineman (Eds.), Laboratory Techniques in Electroanalytical Chemistry, $2^{\text {nd }}$ Ed., Marcel Dekker, New York, 1996.

22. N. Ozaltin, A. Temizer, Electroanalysis 6 (1994) 799-803.

23. D. Dogrukol, M. Tuncel, Pharmazie 50 (1995) 701-702. 
24. S. Pinzauti, P. Gratteri, S. Furlanetto, P. Mura, E. Dreassi, R. Phan-TanLuu, J. Pharm. Biomed. Anal. 14 (1996) 881-889.

25. H. Oelschlager, H. Knoth, Pharmazie 53 (1998) 242-244.

26. C. Yardimci, N. Ozaltin, Analyst 126 (2001) 361-366.

27. S. McClean, E. G'Kane, V.N. Ramachandran and W.F. Smyth, Analytica Chemica Acta 292 (1994) 81-89.

28. J.M. Shin, Y.M. Cho, G. Sachs, J. Am. Chem. Soc. 126 (2004) 7800-7811.

29. A.M. Qaisi, M.F. Tutunji, L.F. Tutunji, J. Pharm. Sci. 95 (2006) 384-391.

30. M.F. Tutunji, A.M. Qaisi, B.El-Eswed, L.F. Tutunji, J. Pharm. Sci. 323 (2006) 110-116. 